\title{
The Impact of Trade Agreement on Agricultural Trade Flow in West Africa
}

\author{
Christiana Manu ${ }^{1}$ \\ ${ }^{1}$ Accra Technical University, Faculty of Business, Marketing Department, Accra, Ghana \\ Correspondence: Christiana Manu, Accra Technical University, Faculty of Business, Marketing Department, \\ Accra, Ghana. Tel: 020-816-9950. E-mail: cmanu@ atu.edu.gh
}

Received: October 29, 2020

Accepted: December 10, 2020

Online Published: December 22, 2020

doi:10.5539/ijef.v13n1p89

URL: https://doi.org/10.5539/ijef.v13n1p89

\begin{abstract}
This paper analysed the impact of trade agreements on agricultural trade flow in West Africa. The study used 25 major trading partners of Ghana for 25 years between 1995 and 2019. Using the Gravity econometric model, this study finds that being a member of the trade agreement (FTA) is positively related to the aggregate flow of trade in agriculture. Trade agreements are found to increase trade flow with trading in agricultural products; especially trading partners in ECOWAS, if members agree on free trade in such products. The result shows that Ghana's bilateral exports significantly increase with an increase in domestic and partner wages, and with distance, they decrease significantly. FTA was found to be a positive and significant determinant of Ghana's bilateral trade in the long and the short run as well. Therefore, when there is a free trade agreement between countries, they tend to trade more among themselves than countries without the trade agreement.
\end{abstract}

Keywords: Ordinary Least Square, gravity model, free trade agreement, cointegration, stationarity, cross sectional dependency

\section{Introduction}

\subsection{Introduction}

The gravity model has been the mainstay of applied international trade literature over the last 50 years. One of the popular ways in modern econometrics is the gravity model of trade. The definition of commercial gravity is adapted from a simple physical theory, where an object's mass induces a force of attraction that decreases with increasing distance. Gravity's key comparative strength in economics comes from the capacity to use real data to test the responsiveness of trade flows concerning policy variables. In the global economy, trade agreements are traditionally signed between several countries in both intracontinental and intercontinental agreements. Trade Agreements are forms of trade treaties signed among countries that eliminate a significant number of tariffs, quotas, and other barriers of trade between involved partners with the ultimate goal of increasing trade volumes between the parties due to the relaxation or removal of those existing institutional and economic barriers. Examples of trade agreement include those between Economic West Africa Countries (ECOWAS), the North American Free Trade Agreement between the USA, Canada, and Mexico (NAFTA), and the Euro-Mediterranean Free Trade Agreement (EMFTA). Most developing economies, especially those in Africa can be impacted significantly by the quality and amount of trade agreements they sign; hence are very much concerned and interested in determining the economic effects of such agreements. The effects of such agreements on a country's agriculture by trade agreement vary depending on the countries or continents involved (Baier \& Bergstrand, 2004). Most developing nations often have reservations for international trade agreements since their economy is predominantly agric based; developed nations (counterparts) on the other hand often enter into these trade agreements in a bid to protect their agriculture sector (Svatoš \& Smutka, 2010). The agriculture sector creates employment as well as contribute to other economic sectors such as the food processing industries, generating more exports for foreign currency and domestic savings. For this reason, developing countries are more oriented towards protecting the agricultural sector of their economies through restrictions such as a high tariff on imports especially on agricultural produces.

\subsection{Problem Statement}

It is essential and worthwhile to explore the effect of trade agreements on both exports and imports of agricultural products. Trade agreements have attracted a significant number of studies focusing on the impact of 
trade agreements (TA) on the economy with most extant researches examining the impacts of trade agreements on trade volumes, economic development, welfare, foreign direct investment (FDI), the setting, costs, industrial sectors, and the agricultural sector, etc. Nevertheless, this area of Trade Agreement is relatively unexplored in most African economies, despite its relevance in the potential growth or depression in the economic growth of developing and low-income countries. Limited studies found in the literature are often inconclusive with some being controversial due to the type of data and methodology employed. Most studies analysing trade flows have either focused on simulation models (Burns, 2012). Computable generalized balance (CGE) concepts have also been extensively used to model trade flows and to examine the impact of trade agreements (Baier \& Bergstrand, 2004; Siriwardana, 2007). But this model has been criticized to be weak and has weak econometric foundations (Hertel et al., 2007).

Several researchers have expressed a high interest in studying the effects of trade agreement by using aspects of the gravity specification. The gravity model has proven to be more preferred by researchers and critics, mainly due to its robust performance and ability to handle limited parametric assumptions, not as both simulated and econometric methods, which were used in an attempt to catch the impact on different variables on trade flows (Filippini \& Molini, 2003). The gravity model has often been referred to as facts without theory by some researchers Since the reliability of its findings with evidence makes it very common for practical uses. with Krugman, (1980); Deardorff and Frankel (1998); Anderson and Marcouiller (1999) providing alternative theoretical foundations for the gravity model.

\subsection{Literature Review}

The study of international trade has enhanced the development of all types of models to explain the movement of knowledge and technology, goods, workers, capital across countries (Barell \& Pain, 1997). In the agriculture trade flow literature and trade agreements, several models and methodologies have been employed though most of these theories of international trade often do not factor in several factors related to the effects of geographical distance, varying prices of products across different regions, etc. Ricardo (1815) proposed the Ricardian model which has been modified since by several authors and researchers. Di Maio (2008) analysed the Impact of rising convergence of trade on an individual country's utility employing a Ricardian standard deterministic model. They provided results to show that higher trade integration decreases prices and raises anticipated real income, whereas higher trade integration often decreases the number of active industries in the economy when raising the cost of unemployment of employees who lose their work when their various industry fails. The Adam Smith Model, which is a classical model in the study of international economics, was proposed by Smith in 1776. The model states that countries can trade so far as there exists an absolute advantage in the production of anyone good by one country over the other. Eaton and Kortum (2002) created a Ricardian model of international trade that integrates a role for geography which captured how geographic barriers inhibit competing forces of comparative advantage that promote trade with results which yielded a simple expression relating bilateral trade volumes to deviate from purchasing power parity, technology, and geographic barriers. Heerman (2013) suggested a generalized equilibrium mechanism for the study of agriculture trade policy that causes considerable variation in the elasticity of market share with regards to the trade costs of a defined exporter across its competing countries and is also able to make more detailed forecasts on how bilateral agricultural trade and development trends shift in reaction to policy changes. This method has the significant benefit of providing a product-level conceptual model to be parameterized, which relies on less data than the commonly utilized sector-level data necessary for the use of a generic gravity model.

The gravity model is also used to analyze spatial encounters between various forms of variables. In air cargo studies, gravity models are being used using the general concept of gravity theory in physics. The United States accounting for $13.6 \%$ of global imports with approximately $15 \%$ of the imports being by air from foreign countries, the United States Census Bureau (2019). Alexander and Merkert (2020), employing the gravity model showed that the request for air freight in the US is strongly responsive to shipping prices, maritime freight rivalry among others rather than factors associated with where products were coming from. They opine that Free Trade Agreements, with their abolition of import tariffs, can affect international air freight through legislative liberalization. Using gravity model applications, Yamaguchi (2008) assessed US export and air transport regulations such as open skies among its trading partners and found that open skies market policy increased the cost of air cargo units, possibly due to congestion in core hubs, which seems to be counterintuitive to the main objective of liberalization of air transport in fostering competition by lowering costs for the satisfaction of customers.

Çekyay et al. (2020) utilized a gravity model to analyse extra costs of transportation by transit and bilateral quotas and its effect on international trade between Turkey and EU countries. Their results indicated that the 
costs of transportation caused by the quotas had substantial consequences on Turkish total exports specifically on food and beverages and the machinery \& equipment sectors. Leng et al. (2020) adopting the gravity model to examine and measure China's wind energy products' export possibilities and its predictors in the market of the Belt and Road countries, produced results that indicated that the geographic distance between China's capitals and importing countries have a detrimental impact on China's trade in wind power products with the Belt and Road nations. Again, Cantore and Cheng (2018), adopted a gravity model to study the impact of multiple factors including geographical proximity, cultural ties, the capacity to innovate, etc on international trade of Environmental goods with results shows that trade in environmental products depends on conventional factors that influence trade in other goods, like GDP, transaction fees and uncertainties. Again, Nasrullah, et al. (2020) used a gravity model approach to examine factors influencing China's forest product group trade with their results revealing that distance has an inverse impact on trade though GDP had a positive impact on trade and that likewise, APEC and the OECD have had a major effect on China's bilateral trade in forest resources. They concluded the promotion of exports and imports to countries with shorter distance intervals was much recommended. Tatoglu and Gul (2019), whiles using the panel gravity model for estimating the predictors of the movement of foreign tourists between locations produced results which indicated that international tourist streams are a negative distance feature and tourist arrivals are highly dependent on other economic factors, including revenue and trade factors, which are important determinants of tourist arrivals.

Extant studies used different econometric techniques of the gravity model, but some of them utilized static panels, some included the dynamic. Ravishankar and Stack (2014) an increased level of integration of the East-West trade frontier was recorded, with nearly two-thirds indicating a low degree of trade opposition when they used a stochastic gravity model frontier requirement to research the effectiveness of East-West trade integration. Jagdambe and Kannan (2020) analysed the impacts on agricultural trade by the trade creation and trade diversion effect among the member countries of the ASEAN-India Free Trade Agreement (AIFTA) using an ordinary least square gravity model and Poisson Pseudo-Maximum Likelihood (PPML) methods of estimation Their results suggested that the agricultural sector of the party countries can encourage trade liberalization in the FTAs as there have been signs of the pure trade creation impact of AIFTA, MERCOSUR, and EU-15 with a greater trade creation impact than the trade diversion impact of AIFTA, SAPTA and NAFTA in the period fixed-effect model, time and country fixed-effect model, respectively. Pfaffermayr (2019) introduced a restricted, projection-based Poisson pseudo maximum likelihood estimation procedure (constrained PPML) that abuses the requirements of equilibrium for estimation and inference. His proposed procedure avoids estimating Significant numbers of fixed exporters and importers effects which are characteristic of the structural gravity model whiles still providing an assertion that is more accurate than the unregulated PPML estimator because the PPML estimator fully projects out the exporter and importer dummies. The Structural gravity models are dependent on monopolistic competition and growing returns to scale the MC-IR model, which typically emphasises the elasticity of consumption substitution and general equilibrium comparative statics (e.g., Bergstrand et al., 2013). Santeramo and Morelli (2016) employed the Quantile Poisson pseudo-maximum likelihood (PPML) estimations of the gravity model to determine the request for Italy's foreign tourists and provided results to indicate that geographical distance the origin countries among other factors were the main influence of the rhythm of agro-tourism to Italy.

This paper seeks to contribute to extant empirical literature which is a bit limited especially with regards to Africa and also provides a systematic review of current researches on trade flow modelling by assessing the impact of the trade agreement on the agricultural sector. With the aid of the gravity model parameters, the research will also explore the causal effects of trade agreements and agriculture. The rest of the paper is arranged in the following order: a summary of the various modelling methods for understanding trade flows is included in the next section. Then the model of gravity is briefly discussed and a structure is provided for classifying current studies. The gravity model is then modified incorporating other variables such as past colonial connection in the next section of this paper. Analysis of data from west African economies is then conducted with the results interpreted for further recommendations to government policymakers and academia.

\subsection{Hypotheses}

The study is guided by the following null hypotheses;

$H_{0}$ : There is no significant relationship between trade agreements and agricultural trade flow in West Africa.

$H_{1}$ : There is a significant relationship between trade agreements and agricultural trade flow in West Africa.

\section{Method}

The main concern of this section is to develop the main statistical framework to be used in examining 
associations or interactions sought in this study. and present the analysis of the projected outcomes of the gravity models on bilateral trade flows.

\subsection{Variable Description}

In line with the gravity model, the sequence of trade between nations is defined mainly by the distance and economic size of trading nations. The model specifies that countries with a higher economy may generate, utilize, and sell most. These countries are expected to produce and spend more income through the importation of other commodities. In this paper, the bilateral trade flow was measured using Ghana's bilateral exports and was the dependent variable. Table 1 , provides details of the variable descriptions.

Table 1. Variable description

\begin{tabular}{|c|c|c|}
\hline Variables & Description & Expectation \\
\hline \multicolumn{3}{|l|}{ Dependent } \\
\hline Export & Ship (goods or services) to another country for sale. & \\
\hline \multicolumn{3}{|c|}{ Independent } \\
\hline$G D P_{i}$ & Gross Domestic Product for reporting country $i$ & Positive \\
\hline$G D P_{j}$ & Gross Domestic Product for reporting country $j$ & Positive \\
\hline $\operatorname{Pop}_{i}$ & Population for reporting country $i$ & Positive \\
\hline $\mathrm{Pop}_{j}$ & Population for reporting country $j$ & Negative \\
\hline$D I S T_{i j}$ & Distance between reporting and partner countries $i$ and $j$ & Negative \\
\hline Colony $_{i j}$ & Dummy $=1$, if country $i$ and $j$ have common language & Positive \\
\hline$F T A_{i j}$ & Dummy $=1$, if country $i$ and $j$ have the FTA & Positive \\
\hline$L A N G_{i j}$ & Dummy $=1$, if country $i$ and $j$ have colony connection & Positive \\
\hline
\end{tabular}

\subsection{Gravity Model}

The main contribution of this research is to outline the methodological technique utilized in this research to achieve the study's objectives. The paper is written in 3 major parts. A short overview of the variables used in the analysis is described in the first section: how they were determined and the publications from which they were extracted. In the second section of the chapter, model specifications, and the theoretical context of the study were discussed. The last segment of the paper addressed problems linked to econometric methodologies, like pooled, fixed effects and random effects estimators, panel unit roots and cointegration tests, and the calculation of long-run relations.

To examine the determinants of Ghana's bilateral trade flows inside the gravity model, this research uses a panel dataset of yearly reports on a cross-section of Ghana's 25 major trading partners for 25 years from 1995 to 2019 , collected from various secondary sources. The selection of the sample period and cross-sectional countries in this analysis is determined by the existence of data on all the factors included in the research and the significance of the total merchandise trade in Ghana over the sample period for each nation (expressed in terms of its percentage share).

Concerning the theoretical model employed in this research, we have used two sets of explanatory factors as the predictors of Ghana's bilateral exports. The inbuilt distribution circumstances in the exporting country and the external market conditions in the importing country are accounted for by the first group of variables, namely gross domestic product (GDP) and population (POP); and the second group of variables is the geographic gap between Ghana's economic centres (i.e. the capital cities) as well as its trading allies. (DIST).

\subsection{Model}

This section specifies the general framework for analysing panel data which allows the researcher great flexibility in modelling distinctions in the behaviour of $\mathrm{N}$ cross-section units $(i, j: 1,2, \ldots, N)$ over $T$ years $(t: 1,2, \ldots, T)$. The basic framework for the gravity model is similar the generalized regression model of the form;

$$
Y_{i t}=\alpha+X_{i t}^{\prime} \beta_{i}+\varepsilon_{i j}
$$

where $Y_{i t}$ is the dependent variable; $i$ represent the cross-sectional dimension for individual countries, $t$ is the time series dimension of the data, $\alpha$ is the regression constant; where relevant the intercept/country-specific fixed-effects $\left(\alpha_{i}\right)$ is expanded to include time trends. In essence, the intercept, time patterns and the slope coefficients $(\beta-\mathrm{i})$ are permitted to differ across different countries. The incorporation of country-specific fixed effects and time patterns enables us to grasp any missing data that are believed to be constant in the long-term relationship (Sakyi, 2011). Also, $\varepsilon_{i j}$ is the random disturbance term (error). To estimate the study parameters, 
the Ordinary least square (OLS) was adopted; which is the econometric equivalent of the lines of best fit used to show the relationship between trade and GDP, population, colony, language, FTA and geographical distance.

In this analysis, OLS is adopted because its estimates inside the available linear model class are coherent, impartial, and effective. OLS is reliable since its coefficient estimates are expected to align with the values of the population as the sample size rises. It is also impartial because the estimates of the OLS coefficient are not uniformly distinctive of the population, although they are dependent on a sample instead of the population as a whole. Finally, efficiency of OLS estimates emanates from the fact that for the estimated coefficients, there is no other linear, impartial estimator which generates lower standard errors.

Let define $\beta_{i}=\left(\beta_{1 i}, \beta_{2 i}, \beta_{3 i}, \ldots, \beta_{k i}\right)$ is a vector of $K \times 1$

And let $X_{i t}=\left(X_{1 i}, X_{2 i}, X_{3 i}, \ldots, X_{k i}\right)$ is the $i t^{t h}$ observation of $K$ explanatory variables and $\varepsilon_{i j}$ is the noise term.

Using the baseline gravity model, we describe dependent and independent variables that hypothesize that trade flows between two countries are a growing function of the size of the countries defined by their GDPs and a declining function of the transportation costs defined by the gap between the two countries. The basic model of gravity, similar to the law of gravity in physics by Isaac Newton, takes a functional form:

$$
\Lambda_{i j t}=\alpha\left(\frac{G D P_{i t}^{\beta_{1}} \times G D P_{j t}^{\beta_{2}}}{D I S T_{i j}^{\beta_{3}}}\right)
$$

Taking natural logarithm of both sides

$$
\operatorname{In} \Lambda_{i j t}=\operatorname{In} \alpha+\operatorname{In} G D P_{i t}^{\beta_{1}}+\operatorname{In} G D P_{j t}^{\beta_{2}}-\operatorname{InDIST} T_{i j}^{\beta_{3}}
$$

The use of the log-linear form enables the coefficients to be interpreted as trade flow elasticity with regard to the explanatory variables;

$$
\operatorname{In} \Lambda_{i j t}=\delta+\beta_{1} G D P_{i t}+\beta_{2} G D P_{j t}+\beta_{3} D I S T_{i j}+\varepsilon_{i j}
$$

Some reviewed empirical studies report that equation (4) fits data well and gives reliable results. As its examined in the literature, countries' population growth influences trade flows, but is exempted from this equation. An enhanced version of the fundamental gravity model specified in (4) is estimated in this report. This is achieved by integrating other variables between pairs of countries that promote or hinder trade flows. The equation of increased gravity used in this research is represented as follows;

$$
\begin{gathered}
\operatorname{In} \Lambda_{i j t}=\delta+\gamma_{i j}+\vartheta_{t}+\beta_{1} \operatorname{lnGDP} P_{i t}+\beta_{2} \ln G D P_{j t}+\beta_{3} \ln P O P_{i t}+\beta_{4} \ln P O P_{j t}+\beta_{5} \ln D I S T_{i j}+ \\
\beta_{6} \operatorname{COLONY}_{i j}+\beta_{7} L A N G_{i j}+\beta_{8} F T A_{i j}+\varepsilon_{i j t}
\end{gathered}
$$

where $\delta$ is the general intercept, $\gamma_{i j}$ accounts for country-specific effects, including unobservable characteristics, associated with a given country pair that have historically affected bilateral trade flows, $\vartheta_{t}$ accounts for time-specific effects and $\beta_{1}, \beta_{2}, \ldots, \beta_{8}$. In $\Lambda_{i j t}$ represent the dependent variable (Ghana bilateral export), which is the exports of the goods or services from country $i$ (Ghana) to country $j$ at time $t$. The independent variables are $\ln G D P_{i t}$ Gross Domestic Product for reporting country $i$, $\ln G D P_{j t}$ Gross Domestic Product for partner country $j$. $\ln P O P_{i t}$ Population of reporting country $i, \ln P O P_{j t}$ Population of partner country $j$. While $\ln D I S T_{i j}$ measures the geographical distance between country $i$ and $j$ from their economic centre (capital city in most cases). COLONY $Y_{i j}$ is dummy which represent 1 if country $i$ and $j$ have colony connection. Because language similarities play a key role in the trading of a binary variable, LANG, that represents the value of one if the language is the same and zero if the language is unique. $F T A_{i j}$ is a dummy vector representing 1 if the nation is a part of the free trade agreement (FTA).

\section{Results}

This section offers a general grounding in the gravity model and its relation to the results. We start the study instinctively, and mention the key fundamentals underlying the gravity model. We use descriptive statistics and the gravity model to examine if these concepts are currently expressed in a dataset of bilateral trade in services.

The primary issue of this segment, therefore is to examine and show the summary statistics of the bilateral trade flow gravity models. Bilateral trade encompasses exports, GDP, growing populations and global distances.

\subsection{Descriptive Statistics}

The study provides details of the study variables and there were 178 observation. Over the study period, the average of natural logarithm export was 3.511 with standard deviation of 0.919 and range of 2.478. Also, the mean of natural logarithm geographical distance was 8.407 with standard deviation and range of 4.38. 
Table 2. Descriptive statistics

\begin{tabular}{ccccc}
\hline Descriptive & Mean & Std Dev & Minimum & Maximum \\
\hline lnExport & 3.511 & 0.919 & 2.043 & 4.525 \\
$\ln G D P_{i t}$ & 5.056 & 2.129 & 1.713 & 7.195 \\
$\ln G D P_{j t}$ & 12.238 & 0.019 & 12.215 & 12.265 \\
$\ln P O P_{i t}$ & 8.39 & 2.318 & 4.152 & 10.749 \\
$\ln P O P_{j t}$ & 10.663 & 4.029 & 4.088 & 14.967 \\
$\operatorname{lnDIST}_{i j}$ & 8.407 & 1.884 & 5.488 & 9.868 \\
\hline
\end{tabular}

Source: World Bank, 2020.

\subsection{Correlation Coefficient}

The study examines the correlation between the study variables. The study revealed that there exists a strong positive correlation between export and GDP (intra and extra) with a respective correlation coefficient as 0.8945 $(\mathrm{P}$-value $=0.00)$ and $0.8579(\mathrm{P}$-value $=0.00)$; export and population growth (extra) with 0.7949 as the correlation coefficient. Moreover, there exists a moderate negative (-0.6425) correlation between geographical distance and export. Thus, as geographical distance decreases (closer distance), export increases.

Table 3. Correlation coefficient

\begin{tabular}{|c|c|c|c|c|c|c|}
\hline Correlation & lnExport $_{i t}$ & $\operatorname{lnGDP_{it}}$ & $\ln G D P_{j t}$ & $\ln P O P_{i t}$ & $\ln P O P_{j t}$ & ${\ln D I S T_{i j}}_{i}$ \\
\hline $\operatorname{lnExport}_{i t}$ & 1 & & & & & \\
\hline $\ln G D P_{i t}$ & $0.8945^{* * *}$ & 1 & & & & \\
\hline $\ln G D P_{i t}$ & $0.8579 * * *$ & $0.263^{*}$ & 1 & & & \\
\hline $\ln P O P_{i t}$ & $0.6861 * * *$ & $0.3868^{*}$ & $0.5233^{* *}$ & 1 & & \\
\hline $\ln P O P_{i t}$ & $0.7949^{* * *}$ & $0.2929 *$ & $0.4442 * *$ & $0.3888^{*}$ & 1 & \\
\hline $\operatorname{lnDIST}_{i j}$ & $-0.6425 * * *$ & $0.3175^{*}$ & $0.3266^{*}$ & $0.2471 *$ & $0.4495 * *$ & 1 \\
\hline
\end{tabular}

Note. $* * * \mathrm{p}<0.001,{ }^{*} * \mathrm{p}<0.05,{ }^{*} \mathrm{p}<0.1$.

Source: World Bank (2020).

\subsection{The Estimated Results of the Gravity Models in Integrated Panels}

Hausman test indicates a Fixed Effect estimator is the most suitable for analysis sought in this study. Following Faruqee, 2004, and Fidrmuc, 2009, respectively, this research first utilizes panel unit root and panel cointegration tests, to analyze the integration properties of the panel series and the long-term relationships between the variables used in the research.

\subsubsection{Panel Unit Root Tests Results}

We evaluate the stationary or integrational properties of the time-variant variables that join the gravity model, comprising population, exports, per capita GDP differential, and geographical distance, as a prerequisite for panel cointegration tests. This is accomplished by using Levin Lin Chu (LLC) and Im, Pesaran and Shin (IPS) panel unit root tests on the variables from 1995-2019. Whereas the LLC test is dependent on the presumption of the general unit root mechanism that the coefficients of the autocorrelation of the tested variables through cross-sections are similar (implying an alternative stationary hypothesis in all panel units), the IPS test depends on the presumption of the individual unit root mechanism that the coefficients of autocorrelation differ throughout cross-sections. Individual intercepts and individual intercepts plus deterministic time trends were included in all the test specifications. With a maximum lag of 6 for the LLC and IPS tests, the Schwarz-Bayesian Information Criterion (BIC) was used to determine the country-specific lag time for the ADF regressions. The test findings are shown in Table 4.

Table 4. Panel unit root tests results

\begin{tabular}{lcccc}
\hline LLC & \multicolumn{2}{c}{ IPS } & Level & First-Difference \\
\cline { 2 - 5 } Variables & Level & First-Difference & -1.1295 & $-2.9345^{* * *}$ \\
\hline Export & 1.3396 & $-2.7753^{* * *}$ & -1.2533 & $-2.9015^{* * *}$ \\
$G D P_{i}$ & -1.1325 & $-6.6125^{* * *}$ & -0.8918 & $-2.7692^{* * *}$ \\
$G D P_{j}$ & 1.3827 & $-4.1858^{* * *}$ & -1.2533 & $-2.8482^{* * *}$ \\
Pop $_{i}$ & -1.1325 & $-4.7596^{* * *}$ & -1.2573 & $-2.5181^{* * *}$ \\
Pop & -1.1237 & $-2.4808^{* * *}$ & -0.092 & $-2.3461^{* * *}$ \\
Distance & 1.0334 & $-3.3931^{* * *}$ & & \\
\hline
\end{tabular}

Note. $* * *$ represents significance at $1 \%$ levels. 
The findings of the IPS and LLC panel unit root test show that all the variables, export, GDP (intra and extra), population growth (intra and extra), and geographical distance are non-stationary at the level with an individual intercept. However, both IPS and LLC panel unit root tests indicate all the study variables are stationary at the first difference at 1 percent significance level.

Instinctively, this implies that there is very good proof that these variables are implemented from order one based on LLC and IPS studies (i.e. I (1)).

\subsection{Panel Cointegration Tests Results}

Table 5 provides the results or the presence of a long stable relationship between the I(1) variables, as proposed by Pedroni $(2000,2004)$.

Table 5. Panel cointegration tests results

\begin{tabular}{lcc}
\hline & Statistic & $p$-value \\
\hline Pedroni's Panel & & \\
Modified Phillips-Perron t & -3.3809 & 0.0004 \\
Phillips-Perron t & -3.1878 & 0.0007 \\
Augmented Dickey-Fuller t & -2.0009 & 0.0227 \\
\hline
\end{tabular}

Source: Author computation, 2020.

From Table 5, for Pedroni's panel, two (2) of the three (3) panel statistics (i.e. panel Philips-Perron t (PP)- and Updated Philips-Perron t-statistics) firmly rejected the null hypothesis that there was no cointegration between the variables at the 5\% significance level, considering export logarithms as dependent variables.

Thus, five (5) of the eight test statistics firmly rejected the null hypothesis, in favor of the alternative hypothesis of cointegration of the panel between the variables. The consequence of these findings is that there is clear proof of an ongoing substantive long-term relationship.

\subsubsection{Analysis of the Estimated Pooled OLS and Fixed Effects}

Given the nature of the dataset used in this analysis, the researcher must choose an effective estimation technique that represents the diversity of the gravity models emerging from the inclusion in the panel data of person and time impact. Doing this, the study begins with a Hausman test to decide between fixed effects (FE) and random effects (RE) models. The p-value of the Hausman test is greater than 0.05. this implies that the required model is the fixed effect.

Table 6. Hausman test

\begin{tabular}{lc}
\hline \multicolumn{2}{c}{ Hausman fixed random } \\
\hline Chi-sq(8) & 22.88 \\
p-value & 0.0004 \\
\hline
\end{tabular}

Table 7. Fixed Effects (FE) Estimates of the Augmented Gravity Models of Ghana, 1995-2019

\begin{tabular}{|c|c|}
\hline Estimated Method & Fixed-effect \\
\hline \multirow[t]{2}{*}{$\ln G D P_{i}$} & 0.4674 \\
\hline & $0.000 * * *$ \\
\hline \multirow{2}{*}{$\ln G D P_{i}$} & 11.142 \\
\hline & $0.000 * * *$ \\
\hline \multirow{2}{*}{$\ln P O P_{i}$} & 0.0014 \\
\hline & 0.841 \\
\hline \multirow{2}{*}{$\ln P O P_{i}$} & 0.004 \\
\hline & 0.506 \\
\hline \multirow[t]{2}{*}{$\operatorname{lnDIST}_{i j}$} & -3.0916 \\
\hline & $0.000 * * *$ \\
\hline \multirow[t]{2}{*}{$\operatorname{COLONY}_{i j}$} & 7.1402 \\
\hline & $0.000 * * *$ \\
\hline \multirow[t]{2}{*}{$L A N G_{i j}$} & 6.754 \\
\hline & $0.000 * * *$ \\
\hline \multirow[t]{2}{*}{$F T A_{i j}$} & 5.3248 \\
\hline & $0.000 * * *$ \\
\hline \multirow[t]{2}{*}{ Cons } & -134.5 \\
\hline & $0.000 * * *$ \\
\hline
\end{tabular}




\begin{tabular}{|c|c|}
\hline $\begin{array}{c}\text { Sigma_u } \\
\text { Sigma_e } \\
\text { Rho }\end{array}$ & $\begin{array}{l}0.1654 \\
0.0118 \\
0.995 \\
\end{array}$ \\
\hline $\begin{array}{l}\text { Prob }>\text { chi2 }=0 \\
F(8,617)=620.35 \\
\text { corr }\left(u \_i, X b\right)=-0.9902(0.994) \\
\text { Adj R-square } \\
\text { Root MSE }\end{array}$ & \\
\hline $\begin{array}{l}\text { Number of Obs } \\
\text { Number of group }\end{array}$ & $\begin{array}{l}33 \\
3 \\
\end{array}$ \\
\hline
\end{tabular}

Source: World Bank (2020).

According to the fixed effects result for export elasticities of all the conventional gravity variables presented in table 7, domestic income (GDPi), foreign incomes (GDPj), and geographical distance (DIST) have their theoretically stipulated signs and are highly statistically significant at $1 \%$ error level.

The main weakness of the pooled OLS (POLS) estimator, however, is that the panel structure (time and space dimensions) of the pooled data is overlooked and the normal OLS regression is only calculated. That is, the POLS regression treats all findings as a single sample overall time spans, regardless of the unnoticeable individual or country-specific impacts. This ignorance of the impact of unnoticed diversity on bilateral trade flows allows the mistakes to autocorrelate and greatly misrepresents the conclusions derived from the estimates. It was shown by Cheng and Wall (2005) and Serlenga and Shin (2004) that overlooking heterogeneity translates into skewed bilateral trade relations estimates.

We also show the findings using the fixed effects (or in the community (FE-WG)) to resolve this question about skewed estimates of the POLS estimator because of an absence of country-specific effects. We viewed the country-specific influences as fixed in estimating the FE model.

The Hausman test firmly rejects the null hypothesis that both estimators are reliable and that there is no substantial variation in their various coefficients because the corresponding p-values are less than 1 percent error level. This, interpreted differently, leads to a clear rejection of the null hypothesis that reliable estimates are given by the RE estimator. The analysis thus concluded based on the Hausman test, that the FE estimator is sufficient for the estimation of the export models. Additionally, the rest of this section is dedicated to the study of the effects of the gravity models of the FE estimator on bilateral trade and exports.

3.4.2 Panel Cointegration Estimation of the Long-Run Coefficients Using the Panel FMOLS and Pooled Mean Group (PMG) Estimators

Completely Modified OLS (FMOLS) due to Kao and Chiang (2000) and the pooled mean group (PMG) suggested by Pesaran, Shin and Smith (1999) are also carried out in estimating the long-run parameters of the gravity models of Ghana's exports. To address the possible endogeneity bias as well as the existence of serial correlation provided by the OLS estimates, the panel FMOLS estimate includes the estimation of the static long-run relationship increased by the leads and lags of the first-differenced regressors. While this method increases the effectiveness of the long-run forecasts, the short-run behaviour is not captured. We used the PMG estimator as a result. The PMG estimator is a panel extension with an error correction interpretation of the single equation ARDL model, which makes it easy to efficiently estimate long-run coefficients while providing short-run behavior information. The findings of long-run coefficients from the estimators of Completely Modified OLS (FMOLS) and pooled mean group (PMG) are shown in Table 8.

Table 8. Panel cointegration estimation of the long-run coefficients using the panel FMOLS and Pooled Mean Group (PMG) estimators

\begin{tabular}{|c|c|c|}
\hline Estimator & Panel FMOLS & Pooled Mean Group (PMG) \\
\hline Regressors & Model 1 & Model 2 \\
\hline \multirow{2}{*}{$\ln G D P_{i t}$} & $0.4881^{* * *}$ & $1.548 * * *$ \\
\hline & $(0.000)$ & $(0.000)$ \\
\hline \multirow{2}{*}{$\ln G D P_{j t}$} & $8.9913 * * *$ & $4.824 * * *$ \\
\hline & $(0.000)$ & $(0.000)$ \\
\hline \multirow{2}{*}{$\ln P O P_{i t}$} & 0.0009 & 0.0100 \\
\hline & $(0.328)$ & $(0.127)$ \\
\hline \multirow{2}{*}{$\ln P O P_{j t}$} & $0.3648 * * *$ & $0.195^{* *}$ \\
\hline & $(0.000)$ & $(0.021)$ \\
\hline
\end{tabular}




\begin{tabular}{|c|c|c|}
\hline $\operatorname{lnDIST}_{i j}$ & $\begin{array}{l}-0.602 * * * \\
(0.000)\end{array}$ & $\begin{array}{l}-1.050^{* * * *} \\
(0.001)\end{array}$ \\
\hline$C^{C O L O N Y} Y_{i j}$ & $\begin{array}{l}4.2458^{* * * *} \\
(0.000)\end{array}$ & $\begin{array}{l}3.2145^{* * *} \\
(0.000)\end{array}$ \\
\hline$L A N G_{i j}$ & $\begin{array}{l}0.3671 \\
(0.128)\end{array}$ & $\begin{array}{l}3.2358 \\
(0.587)\end{array}$ \\
\hline$F T A_{i j}$ & $\begin{array}{l}5.0254 * * * \\
(0.000)\end{array}$ & $\begin{array}{l}6.2548 * * * \\
(0.000)\end{array}$ \\
\hline Constant & & $\begin{array}{l}2.350 * * * \\
(0.000)\end{array}$ \\
\hline
\end{tabular}

Source: World Bank 2020.

Here, the InGDPi, InGDPj, Indist, FTA $A_{i j}$, COLONY ${ }_{i j}$ are both significance for both the Panel FMOLS and Pooled Mean Group (PMG) respectively. This also confirms the earlier finding based on the FE estimator. On the other hand, $\operatorname{lnPOP} i t$ and $L A N G_{i j}$ showed up as having consistently insignificant coefficients in most of the long-run estimations for both Panel FMOLS and Pooled Mean Group (PMG).

\subsubsection{The Short-Run Coefficients and the Error Correction Model of the Pooled Mean Group (PMG) Estimator}

The study presents and discusses the short-run effects of the variables entering the gravity models on West African exports in this segment. The purpose of the analysis in this section is to provide important information on the speed of convergence following a short-run shock in the system to the long-run balance (stationary state). In Table 9 below, PMG estimates of short-run parameters are listed.

Table 9. The short-run coefficients and the error correction model of the Pooled Mean Group (PMG) estimator

\begin{tabular}{ccccc}
\hline Independent variables & Coef. & Std. Err. & Z & p-value \\
\hline$\Delta l n G D P_{i t}$ & 11.7747 & 2.4901 & 4.73 & 0.000 \\
$\Delta l n G D P_{j t}$ & 4.0307 & 0.1535 & 26.26 & 0.000 \\
$\Delta l n P O P_{i t}$ & 6.3825 & 2.6383 & 2.42 & 0.016 \\
$\Delta l n P O P_{j t}$ & 1.6505 & 0.8840 & 1.87 & 0.062 \\
$\Delta \operatorname{lnDIST_{ij}}$ & -4.7533 & 2.3424 & -2.03 & 0.042 \\
$\Delta C O L O N Y_{i j}$ & 2.1809 & 0.6308 & 3.46 & 0.001 \\
$\Delta L A N G_{i j}$ & 3.5544 & 1.1947 & 2.98 & 0.003 \\
$\Delta F T A_{i j}$ & 2.1698 & 0.5854 & 3.71 & 0.000 \\
$E C M_{t-1}$ & -0.9051 & 0.2228 & -4.06 & 0.000 \\
\hline Log Likelihood & 97.48 & & & \\
No. of Observations & 33 & & & \\
No. of groups & 3 & & & \\
Observations per group & 11 & & & \\
\hline
\end{tabular}

Source: World Bank 2020.

The $\Delta \operatorname{lnGDPit}$ and $\Delta \operatorname{lnGDPjt}$ have been shown to substantially enhance the export supply of West Africa in the short term, presenting clear evidence of a potential presence in West Africa of the J-curve effect (the export phenomenon following currency appreciation before long-term improvement). In the same vein, population growth (extra $\mathrm{j}$ ) and geographical distance proved to be statistically significant in inhibiting West Africa's export with the sampled partners. Thus, population growth was found to expand West Africa's bilateral exports in the short-run, which is statistically significant. In the case of geographical distance exhibit a negative relationship with West Africa in the short run.

The approximate coefficients of the error-correction term are negative and significant (-0.9051). Instinctively, indicates that after divergence from the long-run in the preceding year the change to the long-run steady-state in the export gravity is rectified by $90.51 \%$ in the present year.

\section{Discussion}

The free trade agreement was positive and significant. This implies that the volume of Ghana's bilateral trade flows with other ECOWAS countries is also positively affected by such preferential trade flows. This result is consistent with Jagdambe and Kannan, (2020) agricultural trade among member countries is high when there are free trade agreements among members. 
The study also found out that Ghana's bilateral exports are positively and substantially influenced by Ghana's GDP (i.e. its productive capacity) and its partner's GDP (i.e. its income). The empirical findings indicate that in describing the pattern of Ghana's bilateral trade flows, the gravity model is very good. Because it was found that the coefficients of the standard gravity variables (domestic and foreign revenues and distance) were strongly compatible with the gravity model's projections. Particularly, with increases in domestic and partner incomes, Ghana's bilateral exports were found to rise substantially and drop substantially over distances. Ghana's bilateral trade flows, as Ghana's population was observed to be negative and statistically important. In comparison, development in the trading partner population has been proven to greatly boost the bilateral export supply of Ghana, owing to the corresponding growth in foreign demand and also to the magnitude of international markets.

\section{Policy Implication}

FTA has been considered to be a good and relevant determining factor of Ghana's bilateral trade in the long and short term too. This suggests that the numerous initiatives aimed at facilitating intra-regional trade in the ECOWAS sub-region have had a substantial positive impact on the member countries' trade flows. Therefore, when there is a free trade agreement between countries, countries tend to trade more and hence policies should be geared towards free trade among countries for production and development.

\section{References}

Alexander, D. W., \& Merkert, R. (2020). Applications of gravity models to evaluate and forecast US international air freight markets post-GFC. Transport Policy. https://doi.org/10.1016/j.tranpol.2020.04.004.

Anderson, J. E., \& Marcouiller, D. (1999). Trade, location and security: An empirical investigation. NBER Working Paper, 7000.

Baier, S. L., \& Bergstrand, J. H. (2004). Economic determinants of free trade agreements. Journal of International Economics, 64(1), 29-63. https://doi.org/10.1016/S0022-1996(03)00079-5

Burns, A. (2012). Global economic prospects. The World Bank, Washington, DC.

Cantore, N., \& Cheng, C. F. C. (2018). International trade of environmental goods in gravity models. Journal of Environmental Management, 223, 1047-1060. https://doi.org/10.1016/j.jenvman.2018.05.036.

Çekyay, B., Kabak, Ö., Ülengin, F., Ulengin, B., Palut, P. T., \& Özaydın, Ö. (2020). A multi-commodity network flow and gravity model integration for analyzing impact of road transport quotas on international trade. Research in Transportation Economics, 100816. https://doi.org/10.1016/j.retrec.2020.100816.

Cheng, I. H., \& Wall, H. J. (2004). Controlling for heterogeneity in gravity models of trade and integration. Working Papers 1999-010, Federal Reserve Bank of St. Louis.

Deardorff, A. V., \& Frankel, J. A. (1998). The Regionalization of the World Economy. Chapter Determinants.

Di Maio, M. (2008). Uncertainty, trade integration and the optimal level of protection in a Ricardian model with a continuum of goods. Structural Change and Economic Dynamics, 19(4), 315-329. https://doi.org/10.1016/j.strueco.2008.07.001.

Eaton, J., \& Kortum, S. (2002). Technology, geography, and trade. Econometrica, 70(5), 1741-1779. https://doi.org/10.1111/1468-0262.00352

Faruqee, M. H. (2004). Measuring the trade effects of EMU (No. 4-154). International Monetary Fund. Retrieved from https://ssrn.com/abstract=878979

Fidrmuc, J. (2009). Gravity models in integrated panels. Empirical Economics, 37(2), 435-446. https://doi.org/10.1007/s00181-008-0239-5

Filippini, C., \& Molini, V. (2003). The determinants of East Asian trade flows: A gravity equation approach. Journal of asian Economics, 14(5), 695-711. https://doi.org/10.1016/j.asieco.2003.10.001

Heerman, K. E. (2013). Technology, ecology and agricultural trade. Retrieved from http://hdl.handle.net/11299/162491

Hertel, T., Hummels, D., Ivanic, M., \& Keeney, R. (2007). How confident can we be of CGE-based assessments of Free Trade Agreements? Economic Modelling, 24(4), 611-635. https://doi.org/10.1016/j.econmod.2006.12.002.

Jagdambe, S., \& Kannan, E. (2020). Effects of ASEAN-India Free Trade Agreement on agricultural trade: The gravity model approach. World Development Perspectives, 100212. https://doi.org/10.1016/j.wdp.2020.100212. 
Kao, C. (1999). Spurious regression and residual-based tests for cointegration in panel data. Journal of Econometrics, 90(1), 1-44. https://doi.org/10.1016/S0304-4076(98)00023-2.

Kao, C., \& Chiang, M. H. (2000). On the Estimation and Inference of Cointegrated Regression in Panel Data. Advances in Econometrics, 15, 179-222. https://doi.org/10.1016/S0731-9053(00)15007-8.

Krugman, P. (1980). Scale economies, product differentiation, and the pattern of trade. The American Economic Review, 70(5), 950-959.

Leng, Z., Shuai, J., Sun, H., Shi, Z., \& Wang, Z. (2020). Do China's wind energy products have potentials for trade with the Belt and Road countries? --A gravity model approach. Energy Policy, 137, 111172. https://doi.org/10.1016/j.enpol.2019.111172

Nasrullah, M., Chang, L., Khan, K., Rizwanullah, M., Zulfiqar, F., \& Ishfaq, M. (2020). Determinants of forest product group trade by gravity model approach: A case study of China. Forest Policy and Economics, 113, 102117. https://doi.org/10.1016/j.forpol.2020.102117

Pedroni, P. (2000). Fully modified OLS for heterogeneous cointegrated panels. Advances in Econometrics, 15, 93-130.

Pedroni, P. (2004). Panel cointegration: asymptotic and finite sample properties of pooled time series tests with an application to the PPP hypothesis. Econometric Theory, 597-625.

Pesaran, M. H., Shin, Y., \& Smith, R. P. (1999). Pooled mean group estimation of dynamic heterogeneous panels. Journal of the American statistical Association, 94(446), 621-634. https://doi.org/10.1080/01621459.1999.10474156

Pfaffermayr, M. (2019). Constrained Poisson pseudo maximum likelihood estimation of structural gravity models. International Economics. https://doi.org/10.1016/j.inteco.2019.11.014

Ravishankar, G., \& Stack, M. M. (2014). The Gravity Model and Trade Efficiency: A Stochastic Frontier Analysis of Eastern E uropean Countries' Potential Trade. The World Economy, 37(5), 690-704. https://doi.org/10.1111/twec.12144

Sakyi, D. (2013). On the implications of trade openness, foreign aid and democracy for Wagner's law in developing countries: Panel data evidence from West African Monetary Zone (WAMZ). The Journal of Developing Areas, 319-339.

Santeramo, F. G., \& Morelli, M. (2016). Modelling tourism flows through gravity models: A quantile regression approach. Current Issues in Tourism, 19(11), 1077-1083. https://doi.org/10.1080/13683500.2015.1051518.

Serlenga, L., \& Shin, Y. (2004). Gravity models of the intra-EU trade: Application of the Hausman-Taylor estimation in heterogeneous panels with common time-specific factors. University of Edinburgh, Mimeo. http://fmwww.bc.edu/repec/esFEAM04/up.8838.1080694540.pdf

Siriwardana, M. (2007). The Australia-United States free trade agreement: An economic evaluation. The North American Journal of Economics and Finance, 18(1), 117-133. https://doi.org/10.1016/j.najef.2006.07.003

Svatoš, M., \& Smutka, L. (2010). Development of agricultural foreign trade in the countries of Central Europe. Agricultural Economics, 56(4), 163-175.

Tatoglu, F. Y., \& Gul, H. (2019). Analysis of tourism demand using a multi-dimensional panel gravity model. Tourism Review. https://doi.org/10.1108/TR-05-2019-0147

US Census Bureau. (2019). US Import and Export Merchandise Trade Statistics. Economic Indicators Division USA Trade Online, US Department of Commerce. Retrieved from https://usatrade.census.gov/data/Perspective60/View/dispview.aspx.

Yamaguchi, K. (2008). International trade and air cargo: Analysis of US export and air transport policy. Transportation Research Part E: Logistics and Transportation Review, 44(4), 653-663. https://doi.org/10.1016/j.tre.2007.05.006

\section{Copyrights}

Copyright for this article is retained by the author(s), with first publication rights granted to the journal.

This is an open-access article distributed under the terms and conditions of the Creative Commons Attribution license (http://creativecommons.org/licenses/by/4.0/). 